\title{
SIMILARITIES BETWEEN COLOR AND WORD COMPOSITIONS
}

Dr. Sandeep Ojha,

Assistant Professor of English, P.M.B. Gujarati Arts and Law College, Indore

E-mail: sandypmb1966@gmail.com

Painting and English Literature depict different aspects of nature and human life. Each color in painting and each word in literature plays an important role in this depiction but a single color or a single word in a work of art is not an absolute entity.

The color and the word gain their complete artistic appeal and symbolic significance in a painting or a work of literature when combined and arranged coherently with other colors and words. Great painters and literary writers have dexterity in selection of colors and words of apt meaning and intensity as well as an ability to create the right composition of colors and words to produce an integrated effect.

Acclaimed painters and literary writers are gifted with a faculty to create new color and word compositions to deal with new subjects. They are able to do so because their creative faculty gets sufficient scope to work on unlimited combinations and arrangements of colors and words available in painting and literature.

Color and word compositions in painting and literature perform the function of creating a bridge between the art and the art lover. Initially, the two compositions in these respective arts catch the art lover's attention. Subsequently, a composition of colors of various shades and intensity in painting and a composition of words with varying shades of meaning and intensity in literature communicates the intended objective of the work of art to the art lover.

The painter and the literary writer are able to depict their subjects with the same accuracy and intensity because the phenomena of color and word compositions operate in identical manner. They also have the same range and communicativeness. Therefore, it becomes possible to transform word composition into color composition and vice versa. This explains why on a large scale themes of paintings have been replicated in literature and literary themes have been depicted in painting. It is also not surprising that many pieces of literature produce a painting like effect and many paintings successfully create epic, tragic, comic, sensuous, aesthetic or other effects found in works of literature.

It is worthwhile to make a mention of the great British poet-painter D.G. Rossetti's (1828-1882) poem The Blessed Damozel remarkable for its pictorial quality. Rossetti has also replicated many descriptions of this poem into a painting. The poem and the painting, when placed side by side, reflect each other accurately.

Stanzas one, two and five of the poem illustrate the potential of literature to produce a painting like effect with the help of word composition. These stanzas paint a vivid picture of a lady standing on the terrace of God's house holding three lilies. There are seven stars in her hair. There is also a 


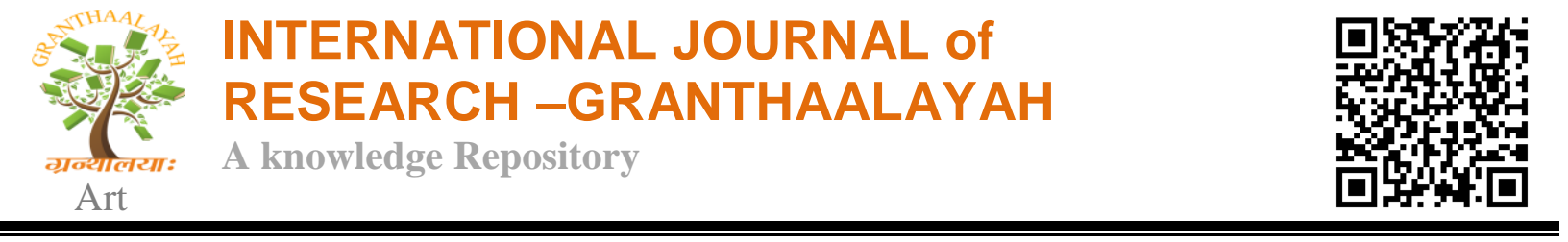

white rose gifted by mother Mary. Her hair, yellowish like ripe corn, lie down her back. She can scarcely see the Sun in the depth of the universe.

The blessed damozel lean'd out

From the gold bar of Heaven;

Her blue grave eyes were deeper much

Than a deep water, even.

She had three lilies in her hand,

And the stars in her hair were seven.

Her robe, ungirt from clasp to hem,

No wrought flowers did adorn,

But a white rose of Mary's gift,

On the neck meetly worn;

And her hair, lying down her back

Was yellow like ripe corn.

It was the terrace of God's house

That she was standing on,--

By God built over the sheer depth

In which Space is begun;

So high that looking downward thence,

She scarce could see the sun.

Thus, there are amazing similarities between color and word compositions. These similarities bring painting and literature so close that quite often a painter appears to describe with colors and a literary writer appears to paint with words. 